\title{
Inhibitory Effects of Quinoline Isolated from Ruta chalepensis and Its Structurally Related Derivatives against $\alpha$-Amylase or $\alpha$-Glucosidase
}

\author{
Jun-Hwan Park • Hoi-Seon Lee*
}

Received: 1 September 2014 / Accepted: 2 September 2014 / Published Online: 31 March 2015

(C) The Korean Society for Applied Biological Chemistry 2015

\begin{abstract}
This study was to isolate an active component of the chloroform fraction from the methanol extract of Ruta chalepensis leaves and to measure inhibitory effects against $\alpha$-glucosidase or $\alpha$-amylase. The inhibitory compound of $R$. chalepensis leaves was isolated using chromatographic methods and identified as quinoline. Quinoline and its structurally related derivatives were tested for their inhibitory activities by evaluating the $\mathrm{IC}_{50}$ values against $\alpha$ amylase or $\alpha$-glucosidase and were compared with that of acarbose. Based on the $\mathrm{IC}_{50}$ values, quinazoline exhibited the greatest inhibitory activity $(20.5 \mu \mathrm{g} / \mathrm{mL})$, followed by acarbose $(66.5 \mu \mathrm{g} /$ $\mathrm{mL})$, and quinoline $(80.3 \mu \mathrm{g} / \mathrm{mL})$ against $\alpha$-glucosidase. In case of $\alpha$-amylase, quinazoline had potent inhibitory activity, followed by quinoline $(179.5 \mu \mathrm{g} / \mathrm{mL})$ and acarbose $(180.6 \mu \mathrm{g} / \mathrm{mL})$. These results indicate that $R$. chalepensis extract, quinoline, and quinazoline could be useful for inhibiting $\alpha$-glucosidase or $\alpha$-amylase.
\end{abstract}

Keywords $\alpha$-amylase $\cdot \alpha$-glucosidase $\cdot$ inhibitory activity $\cdot$ quinoline $\cdot$ Ruta chalepensis

\section{Introduction}

Diabetes mellitus is the most serious global health problem and results in considerable morbidity and mortality (Nilubon et al., 2006). Complications of diabetes such as terminal nephritis and

J.-H. Park $\cdot$ H.-S. Lee

Department of Bioenvironmental Chemistry and Institute of Agricultural Science \& Technology, College of Agriculture \& Life Science, Chonbuk National University, Jeonju 561-756, Republic of Korea

*Corresponding author (H.-S. Lee: hoiseon@jbnu.ac.kr)

This is an Open Access article distributed under the terms of the Creative Commons Attribution Non-Commercial License (http://creativecommons. org/licenses/by-nc/3.0/) which permits unrestricted non-commercial use, distribution, and reproduction in any medium, provided the original work is properly cited. cardiovascular disorders are the principal cause of irreversible blindness (Perez et al., 1998; Jeong et al., 2012). Diabetes falls into two etiopathogenetic categories, types 1 and 2 (American Diabetes Association., 2005; Nilubon et al., 2006). Diabetes type 1 is resulted in absolute deficiency of insulin secretion (Nilubon et al., 2006; Frode and Medeiros, 2008). Diabetes type 2 is caused by insufficient compensatory insulin secretion and a combination of resistance to insulin action (Nilubon et al., 2006; Frode and Medeiros, 2008). Attention to herbal remedies has increased because of the side effects associated with treatment of oral hypoglycemic agents and insulin (Holman and Turner, 1991; Lee, 2005; Kim et al., 2006; Jeong et al., 2012; Lee et al., 2014).

Ruta chalepensis L. (Rutaceae) is a perennial herb that is extensively used in folk medicine. $R$. chalepensis is well-known as an alternative medical therapy (antispasmodic, antirheumatic, aphrodisiac) and a treatment for snakebites, headache, and wounds (Ghazanfar, 1994). Furthermore, this plant is a rich source of several acridones and coumarins, as well as quinoline alkaloids (Ulubelen and Guner, 1988; Ulubelen and Terem, 1988; Lee and Ahn, 1998; Lee, 2002). R. chalepensis exhibits insecticidal activity against pests, with no noxious effects on parasitoids (Almazraawi and Ateyyat, 2009) and shows antibacterial, antifungal, anthelmintic, and anthelmintic effects (Di Stasi et al., 2002; Alzoreky and Nakahara, 2003; Iauk et al., 2004; Yarnell and Abascal, 2004; Cho et al., 2005; Rigat et al., 2007; Barrera-Necha et al., 2009). However, no report on the inhibitory activity of active compound isolated from $R$. chalepensis leaves and structurally related derivatives against $\alpha$-amylase or $\alpha$-glucosidase is available. Therefore, we isolated an active constituent from $R$. chalepensis leaves and assessed the inhibitory effects of quinoline derivatives against $\alpha$-glucosidase or $\alpha$-amylase.

\section{Materials and Methods}

Isolation and identification. $R$. chalepensis leaves were collected from a market in Korea. $R$. chalepensis leaves $(3.0 \mathrm{~kg})$ were 
ground and extracted with methanol $(11 \mathrm{~L})$ at $25^{\circ} \mathrm{C}$ for 1.5 days. The filtrate was poured into a EYELA Autojack NAJ-100 evaporator (Japan) at $45^{\circ} \mathrm{C}$, and the methanol extract $(20 \mathrm{~g})$ was continuously partitioned into hexane fraction $(2.1 \mathrm{~g})$, chloroform fraction $(3.7 \mathrm{~g})$, ethyl acetate fraction $(2.1 \mathrm{~g})$, butanol fraction $(2.6 \mathrm{~g})$, and water fraction $(9.1 \mathrm{~g})$ for subsequent bioassay. Five organic fractions were dried by rotary evaporator at $40^{\circ} \mathrm{C}$, and the water fraction was freeze-dried.

Chloroform (43.8 g) fraction partitioned from the methanol extract was chromatographed on a silica gel column (70-220 mesh, Merck, USA, $540 \mathrm{~mm}$ i.d. $\times 680 \mathrm{~mm}$ ) and eluted with a stepwise gradient of chloroform/methanol $(0,10,20,30,40$, and $100 \%$ methanol, $\mathrm{v} / \mathrm{v})$ and petroleum ether/chloroform $(10: 1, \mathrm{v} / \mathrm{v})$. The column fractions were tested by thin layer chromatography (chloroform/methanol, 10:1, v/v), and active fractions with similar patterns were collected. The active fractions were chromatographed on a silica gel column and eluted with petroleum ether/chloroform/ methanol $(20: 15: 1, \mathrm{v} / \mathrm{v})$. The active fraction $(8.4 \mathrm{~g})$ was isolated by preparative high-performance liquid chromatography (HPLC) (Japan Analytical Industry Co., Ltd., Japan). The first column was a Jai gel GS Series Column (GS310 30+GS310 50 cm) using hexane:chloroform:isopropanol $(40: 60: 2, \mathrm{v} / \mathrm{v})$ at a flow rate of 4.5 $\mathrm{mL} / \mathrm{min}$ and detection at $291 \mathrm{~nm}$. This step afforded four fractions. The active fraction (3. g) was further chromatographed on a Jaigel W Series column (W-252 $50+\mathrm{W}-25350 \mathrm{~cm})$ using hexane:chloroform:isopropanol (40:60:2, v/v) at a flow rate of 5.1 $\mathrm{mL} / \mathrm{min}$. The active component ( $1.4 \mathrm{~g}$ ) was isolated and subjected to structural determination via spectroscopic analyses. The ${ }^{13} \mathrm{C}$ NMR and ${ }^{1} \mathrm{H}-\mathrm{NMR}$ spectra date were studied using a Bruker AM500 spectrometer $\left({ }^{13} \mathrm{C}-400 \mathrm{MHz} ;{ }^{1} \mathrm{H}-100 \mathrm{MHz}\right)$. Ultraviolet spectra and mass spectra were studied using a Waters 490 spectrometer and JEOL JMS-AX 302 spectrometer, respectively.

Chemicals and bioassay. Acarbose, quinazoline, and quinoxaline were supplied from Sigma-Aldrich (USA). The inhibitory effects of $R$. chalepensis extract, quinoline, and its structurally related analogs were evaluated against $\alpha$-glucosidase and $\alpha$-amylase. Inhibitory activity was assayed according to the procedure studied by Lee et al. (2014) and Shinde et al. (2008) with a slight modification against $\alpha$-glucosidase. $p$-Nitrophenol was measured using $\alpha$-glucosidase after reaction with $p$-nitrophenyl- $\alpha$-D-glucopyranoside. $0.6 \mathrm{U}$ Enzyme solution was made by dissolving $\alpha$ glucosidase in $0.1 \mathrm{M}$ phosphate buffer $(\mathrm{pH} 7.0)$ mixing up bovine serum albumin ( $2 \mathrm{~g} / \mathrm{L}, \mathrm{BSA})$ and sodium azide $(0.2 \mathrm{~g} / \mathrm{L}) .50 \mu \mathrm{L}$ Enzyme solution and $10 \mu \mathrm{L}$ sample dissolved in DMSO were blended and placed in a well plate. After $15 \mathrm{~min}, 5 \mathrm{mM}$ p-nitrophenyl- $\alpha$-D-glucopyranoside $(50 \mu \mathrm{L})$ in $0.1 \mathrm{M}$ phosphate buffer was added, and the mixture was incubated for $9 \mathrm{~min}$ at $38^{\circ} \mathrm{C} .0 .1$ $\mathrm{M} \mathrm{Na}_{2} \mathrm{CO}_{3}$ was added to stop the reaction. The absorbance was tested at $405 \mathrm{~nm}$ using a Model ASYS UVM 340 microplate reader (Biochrom Ltd., England). Biological experiments were replicated three times. Inhibition percentage (\%) was evaluated using the equation: Inhibition $(\%)=[1-($ sample/control $)] \times 100$. The $\mathrm{IC}_{50}$ value was calculated by logarithmic regression analysis. Inhibitory activity was assayed in accordance with the procedure studied by Jeong et al. (2012) and Wang et al. (2010) with some modification against $\alpha$-amylase. The enzyme solution $(6.30 \mathrm{U} /$ $\mathrm{mL}$ ) was made by dissolving $\alpha$-amylase (Sigma Co., USA) in 0.5 M Tris buffer (pH 6.9). Starch azure ( $8 \mathrm{mg}$ ) was suspended in 0.5 $\mathrm{M}$ Tris buffer mixing up $0.01 \mathrm{M} \mathrm{CaCl}_{2}$ and soaked in boiling water for $5 \mathrm{~min}$ followed by preincubation at $38^{\circ} \mathrm{C}$ for $9 \mathrm{~min}$. $100 \mu \mathrm{L}$ Enzyme solution and $100 \mu \mathrm{L}$ sample into 50\% DMSO were blended in a well plate. $50 \%$ Acetic acid $(50 \mu \mathrm{L})$ was added to stop the reaction after $10 \mathrm{~min}$. The absorbance was tested at 595 nm with a Model ASYS UVM 340 microplate reader. Biological experiments were replicated three times. Inhibition percentage (\%) was evaluated using the equation: Inhibition $(\%)=[1-($ sample/ control) $] \times 100$.

\section{Results and Discussion}

Five fractions partitioned from methanol extracts of $R$. chalepensis leaves were assessed for inhibitory activity against $\alpha$-glucosidase and $\alpha$-amylase (Table 1). At 1,500 $\mu \mathrm{g} / \mathrm{mL}$, the chloroform fraction showed $100 \%$ inhibition against $\alpha$-glucosidase and $\alpha$-amylase, whereas other fractions exhibited no inhibition. Active compound was isolated by silica gel chromatography and preparative HPLC. The active compound was identified by spectroscopic methods, EI-Mass spectroscopy, ${ }^{13} \mathrm{C}-\mathrm{NMR}$ and ${ }^{1} \mathrm{H}-\mathrm{NMR}$, and by comparison with an authentic reference component. The active component was characterized as quinoline (Fig. 1) based on the following evidence: quinoline $\left(\mathrm{C}_{9} \mathrm{H}_{7} \mathrm{~N}, \mathrm{MW}, 129.2\right)$; EI-MS $(70 \mathrm{eV}) \mathrm{m} / \mathrm{z}(\%$ relative intensity): $\mathrm{M}^{+} 129$ (100), 128 (15), 102 (25), 76 (10), 51 (12); ${ }^{1} \mathrm{H}-\mathrm{NMR}\left(\mathrm{CD}_{3} \mathrm{OD}, 400 \mathrm{MHz}\right)$; d 8.82-8.83 (1H, $m, J=6.12$ $\mathrm{Hz}, \mathrm{H}-2), 8.34-8.36(1 \mathrm{H}, m, J=8.56 \mathrm{~Hz}, \mathrm{H}-8), 8.00-8.03(1 \mathrm{H}, d$, $1 \mathrm{H}, J=8.52 \mathrm{~Hz}, \mathrm{H}-4), 7.92-7.94(1 \mathrm{H}, d, J=8.32 \mathrm{~Hz}, \mathrm{H}-5), 7.74-$ $7.78(1 \mathrm{H}, m, J=17.08 \mathrm{~Hz}, \mathrm{H}-7), 7.58-7.62(1 \mathrm{H}, m, J=16.36 \mathrm{~Hz}$, $\mathrm{H}-6), 7.50-7.53(1 \mathrm{H}, m, J=12.72 \mathrm{~Hz}, \mathrm{H}-3) ;{ }^{13} \mathrm{C}-\mathrm{NMR}\left(\mathrm{CD}_{3} \mathrm{OD}\right.$, $100 \mathrm{MHz}$ ); 150.8 (C-2), 148.4 (C-9), 137.9 (C-4), 130.8 (C-7), 129.4 (C-8), 129.1 (C-10), 128.8 (C-5), 127.7 (C-6), 122.4 (C-3). The spectroscopic data of active constituent isolated from $R$. chalepensis leaves were verified to match those of quinoline (Lee and Lee, 2011).

Quinoline derivatives were selected to evaluate the changes in inhibitory activity based on the position of nitrogen atoms in the

Table $1 \alpha$-Glucosidase and $\alpha$-amylase inhibitory activities of various fractions obtained from the methanol extract of $R$. chalepensis leaf

\begin{tabular}{lcc}
\hline \multicolumn{1}{c}{ Samples $^{\mathrm{a}}$} & $\begin{array}{c}\text { Inhibitory activities (\%) } \\
\text { against } \alpha \text {-glucosidase }\end{array}$ & $\begin{array}{c}\text { Inhibitory activities (\%) } \\
\text { against } \alpha \text {-amylase }\end{array}$ \\
\hline Methanol extract & $64.5 \pm 1.1$ & $72.1 \pm 1.4$ \\
Hexane fraction & $\mathrm{NA}^{\mathrm{b}}$ & $\mathrm{NA}$ \\
Chloroform fraction & 100 & 100 \\
Ethyl acetate fraction & $\mathrm{NA}$ & $\mathrm{NA}$ \\
Butanol fraction & $\mathrm{NA}$ & $\mathrm{NA}$ \\
Water fraction & $\mathrm{NA}$ & $\mathrm{NA}$ \\
\hline
\end{tabular}

${ }^{\mathrm{a} S a m p l e}$ concentration, $1,500 \mu \mathrm{g} / \mathrm{mL}$.

${ }^{b} \mathrm{NA}$, no activity. 
(A)<smiles>c1ccc2ncccc2c1</smiles>

(B)<smiles>c1ccc2ncncc2c1</smiles>

(C)<smiles>c1ccc2nccnc2c1</smiles>

Fig. 1 Chemical structures of the quinoline derivatives. (A) Quinoline. (B) Quinazoline. (C) Quinoxaline.

Table $2 \alpha$-Glucosidase and $\alpha$-amylase inhibitory activities of quinoline and $\mathrm{IC}_{50}$ values of its structural derivatives

\begin{tabular}{lcc}
\hline Samples & $\begin{array}{c}\alpha \text {-glucosidase inhibition } \\
\mathrm{IC}_{50}(\mu \mathrm{g} / \mathrm{mL})^{\mathrm{a}}\end{array}$ & $\begin{array}{c}\alpha \text {-amylase inhibition } \\
\mathrm{IC}_{50}(\mu \mathrm{g} / \mathrm{mL})\end{array}$ \\
\hline Quinoline & $80.3 \pm 2.1$ & $179.5 \pm 1.5$ \\
Quinazoline & $20.5 \pm 1.8$ & $55.4 \pm 1.7$ \\
Quinoxaline & $\mathrm{NI}^{\mathrm{c}}$ & $\mathrm{NI}$ \\
Acarbose $^{\mathrm{b}}$ & $66.5 \pm 1.5$ & $180.6 \pm 1.3$ \\
\hline
\end{tabular}

${ }^{\mathrm{a}} \mathrm{IC}_{50}$ values calculated from regression lines, using five different concentrations in triplicate experiments.

${ }^{\mathrm{b}}$ Acarbose was used as the positive control.

${ }^{\mathrm{N}} \mathrm{NI}$, no inhibition at a concentration of $1,000 \mu \mathrm{g} / \mathrm{mL}$.

pyrazine ring such as quinazoline and quinoxaline against $\alpha$ glucosidase and $\alpha$-amylase (Fig. 1). Quinoline, quinazoline, quinoxaline, and acarbose were tested for their inhibitory activities by measuring their $\mathrm{IC}_{50}$ values against $\alpha$-glucosidase and $\alpha$-amylase. Based on the $\mathrm{IC}_{50}$ values against $\alpha$-glucosidase, quinazoline exhibited the greatest inhibitory activity $(20.5 \mu \mathrm{g} / \mathrm{mL})$, followed by acarbose $(66.5 \mu \mathrm{g} / \mathrm{mL})$, and quinoline $(80.3 \mu \mathrm{g} / \mathrm{mL})$ (Table 1$)$. In case of the inhibitory activity against $\alpha$-amylase, quinazoline had potent inhibitory activity followed by quinoline $(179.5 \mu \mathrm{g} /$ $\mathrm{mL}$ ), and acarbose $(180.6 \mu \mathrm{g} / \mathrm{mL})$ (Table 2$)$. However, quinoxaline did not exhibit any inhibitory activity against $\alpha$-glucosidase or $\alpha$ amylase. Compared with that of acarbose, quinazoline exhibited higher inhibitory activity against $\alpha$-glucosidase than acarbose, but quinoline showed less inhibitory activity against $\alpha$-glucosidase than acarbose. Quinazoline showed higher inhibitory activity against $\alpha$-amylase than that of acarbose. No significant difference was observed between quinoline and acarbose against $\alpha$-amylase. These results indicate that quinoline and quinazoline had the great inhibitory activity against $\alpha$-glucosidase or $\alpha$-amylase. Similarly, Lee and Lee (2011) reported that quinoline and quinazoline showed good relaxant effects on histamine-induced contraction in guinea pig trachea. Interestingly, quinoxaline, which has a nitrogen atom in place of a carbon atom in the pyridine ring, did not exhibit any inhibitory activity against $\alpha$-glucosidase or $\alpha$-amylase. In contrast, quinazoline showed the greatest inhibitory activities against $\alpha$-glucosidase or $\alpha$-amylase. Similarly, previous studies reported that the position of the nitrogen atom in the ring affects $\alpha$ - and $\beta$-glucosidase inhibitory activities (Borges de Melo et al., 2006).

Based on the Material Safety Data sheet provided by SigmaAldrich (2012), the oral lethal dose of quinoline $(262 \mathrm{mg} / \mathrm{kg}$ ) indicates moderate acute toxicity to mammals. Based on our findings, the inhibitory action of quinoline and quinazoline may be useful as an inhibitory agent. However, further work is necessary to determine toxicity to humans.

\section{References}

Al-mazraawi MS and Ateyyat M (2009) Insecticidal and repellent activities of medicinal plant extracts against the sweet potato whitefly Bemisia tabaci (Hom.: Aleyrodidae) and its parasitoid Eretmocerus mundus (Hym.: Aphelinidae). J Pestic Sci 82, 149-54.

Alzoreky NS and Nakahara K (2003) Antibacterial activity of extracts from some edible plants commonly consumed in Asia. Int J Food Microbiol 80, 223-30.

American Diabetes Association (2005) Diagnosis and classification of diabetes mellitus. Diabetes Care 28, 37-42.

Barrera-Necha LL, Bautista-Banos S, Flores-Moctezuma HE, and Estudillo AR (2008) Efficacy of essential oils on the conidial germination, growth of Colletotrichum gloeosporioides (Penz.) Penz. and Sacc and control of postharvest diseases in papaya (Carica papaya L.). Plant Pathol 7, 174 8 .

Borges de Melo E, Da Silveira Gomes A, and Carvalho I (2006) $\alpha$ - and $\beta$ Glucosidase inhibitors: chemical structure and biological activity. Tetrahedron 62, 10277-302.

Cho JH, Lee CH, and Lee HS (2005) Antimicrobial activity of quinoline derivatives isolated from Ruta chalepensis toward human intestinal bacteria. J Microbiol Biotechnol 15, 646-51.

Di Stasi LC, Oliveira GP, Carvalhaes MA, Queiroz-Junior M, Tien OS, Kahinami SH et al. (2002) Medicinal plants used in Brazilian tropical Atlantic forest. Fitoterapia 73, 69-91.

Frode TS and Medeiros YS (2008) Animal models to test drugs with potential antidiabetic activity. J Ethnopharmacol 115, 173-83.

Ghazanfar SA (1994) Handbook of Arabian Medicinal Plants. CRC Press (Boca Raton), 190.

Holman RR and Turner RC (1991) Oral agents and insulin in the treatment of NIDDM. Text Book of Diabetes Blackwell Oxford 467-9.

Iauk L, Mangano K, Rapisarda A, Ragusa S, Maiolino L, Musumeci R et al. (2004) Protection against murine endotoxemia by treatment with Ruta chalepensis L., a plant with anti-inflammatory properties. J Ethnopharmacol 90, 267-72.

Jeong EY, Cho KS, and Lee HS (2012) $\alpha$-Amylase and $\alpha$-glucosidase inhibitors isolated from Triticum aestivum L. sprouts. J Korean Soc Appl Biol Chem 55, 47-51.

Kim SH, Hyun SH, and Choung SY (2006) Anti-diabetic effect of cinnamon extract on blood glucose in db/db mice. J Ethnopharmacol 104, 119-23.

Lee $\mathrm{CH}$ and Lee HS (2011) Relaxant effect of quinoline derivatives on histamine-induced contraction of the isolated guinea pig trachea. $J$ Korean Soc Appl Biol Chem 54, 118-23.

Lee HS (2002) Tyrosinase inhibitors of Pulsatilla cernua rootderived materials. J AgricFood Chem 50, 14003.

Lee HS (2005) Cuminaldehyde: aldose reductase and $\alpha$-glucosidase inhibitor derived from Cuminum cyminum L. seeds. J Agric Food Chem 53, 2446-50.

Lee HS and Ahn YJ (1998) Growth-inhibiting effects of Cinnamomum cassia bark-devived materials on human intestinal bacteria. J Agric Food Chem 
46, 8-12.

Lee HW, Yang JY, and Lee HS (2014) Quinoline-2-carboxylic acid isolated from Ephedra pachyclada and its structural derivatives show inhibitory effects against $\alpha$-glucosidase and $\alpha$-amylase. J Korean Soc Appl Biol Chem 57, 441-4.

Nilubon JA, Megh RB, and Jun K (2006) $\alpha$-Glucosidase inhibitors from Devil tree (Alstonia scholaris). Food Chem 103, 1319-23.

Rigat M, Bonet MA, Garcia S, Garnatje T, and Valles J (2007) Studies on pharmaceutical ethnobotany in the high river Ter valley (Pyrenees, Catalonia, Iberian Peninsula). J Ethnopharmacol 113, 267-77.

Shinde J, Taldone T, Barietta M, Kunaparaju N, Hu B, and Kumar S (2008) $\alpha$-Glucosidase inhibitory activity of Syzygium cumini (Linn.) skeels seed kernel in vitro and in goto-kakizake (GK) rats. Carbohydr Res 343, 1278-81.

Ulubelen A and Guner H (1988) Isolation of dehydromoskachan C from Ruta chalepensis var. latifolia. J Nat Prod 51, 1012-3.

Ulubelen A and Terem B (1988) Alkaloids and coumarins from roots of Ruta chalepensis. Phytochemistry 27, 650-1.

Wang $\mathrm{H}, \mathrm{Du}$ YJ, and Song HC (2010) $\alpha$-Glucosidase and $\alpha$-amylase inhibitory activities of guava leaves. Food Chem 123, 6-13.

Yarnell E and Abascal K (2004) Botanical prevention and treatment of malaria: Part 1. Herbal mosquito repellents. Altern Complement Ther 10, 206-10. 